\title{
Dream: A Brief Comparative Study of Nerval and Keats
}

\author{
Safoora Torkladani, Pyeaam Abbasi \\ University of Isfahan, Isfahan, Iran \\ E-mail: Pyeaam77@yahoo.co.uk
}

Keywords: Nerval; Keats; Dream; Reality; Poetry

\begin{abstract}
Dreams, as reflections of the subconscious, seem to be an essential ingredient of Nerval's and Keats's poetry. The two poets show that poetry is an apt place to explore the blurred boundary and continuity between dream and reality. This idea seems to be in close relation with both poets' search for identity and inner self. The female figure that, also, appears in many of the two poets' poms is closely related with the poets' obsession with dreams in which they seek to ward off depression and find proof for imagination. Nerval and Keats use poetry to understand their dreams and give them shape and meaning. They create mysterious worlds in their poems where dreams and reality are intermingled. In both Nerval and Keats, the significance of dream lies in the fact that it plays the role of a safe haven for the poet who is afraid of the unstable reality and identity. Both seem to seek refuge in dream where a stable identity and a permanent beauty may be found.
\end{abstract}

\section{INTRODUCTION}

Gérard de Nerval grew up with his uncle in Valois, the city that makes up the setting for most of his writings, including Les Filles $d u$ Feu. The memories of his childhood in this city never left him. Richer believes that "Gérard cannot find a heaven more ideal than that of his childhood" (1963, p. 622). Nerval's premature loss of his mother continued to torment him throughout his life: "I never met my mother; her pictures have been lost or stolen" (Nodier, 1974, p.17). Nerval's mother was the star of his life: "the lone star of my life is dead" (Nerval, 1965, p. 54 ).

Perhaps it was this torment that caused in him the development of a superiority complex. $\mathrm{He}$ continually searched for an immortal picture of a female figure as he was, obsessed with creating a vivid portrait of his mother. Throughout his life he traveled to many different European and Eastern countries including Greece, Egypt, Palestine and Lebanon, finally discovering his ideal of woman in the Eastern myths. He felt obliged to be a wanderer and in quest. The quest for a woman who was, much like himself, inspired by a love that could deliver him to his origins; the quest for ancient and painful secrets that normally appear as dreams and memories. In that dream state he was no longer able to differentiate between his actual memories and his imagined wishes, between reality and dream or "wake or sleep" as Keats would say in his "Ode to the Nightingale."

Nerval strived to eradicate the merciless effects of time with his art. For him, art made it possible to search for another form of the passage of time: the past through memories and the future through imagination. The prominence of childhood dreams is conspicuous in his Les Filles de Feu, particularly in Sylvie where the journey and quest seems to be in search of the artist's own inner self or the depths of his soul, made possible through revelation of dreams.

In 1824 he met Jenny Colon, an actress, who was the realization of his ideal woman and mother and thus became his lifelong friend. Her name inspired the name Jemmy for one of the characters in Les Filles de Feu. Their relationship ended with Jenny's marriage but she continued to affect Nerval's works until well after her death.

Nerval's life was intertwined with the concept of dreams, as is perceivable through his literary works. Nerval's poetry and prose are a reflection of his thoughts, affected by his obsession with the dream state. "Le Voyage en Orient" ("Journey to the East") reads like an entertaining tale or legend with undercurrents of comedy. Romances develop in the midst of a journey to Europe and the East as the protagonist searches for that ideal image of woman and of himself. We can arguably add to the theme of wandering the idea of movement and escape into the future. Les filles de feu 
includes different fragments of the author's memories and feelings that all in all deal with the concept of woman who may appear in the form of a mother, sister or a lover. Imagination and observation blend together as the author recreates women from his life with an added element of his own imagination. Sylvie reads like an autobiography, or at least parts of one.

"Aurelia" also called "le rêve et la vie" ("Dream and Life"), deals with a descent into hell, paralleled with the journey to the East. This descent happens in the subconscious and is reflected in dreams in which Nerval seeks to ward off demons and find proof for his thoughts and imagination. He believed dreams to be meaningful and believed that mysterious things that grow in imagination become comprehendible through dreams. The thoughts underlying "Aurelia" shed light on concepts such as purity and salvation, human suffering and mysticism, which bind all those who believe in the purification of the soul. This book is an attempt by the author to bring order and give shape to his dreams and hallucinations.

"Les Chimères" translated as "Hallucinations," is a collection of poems including 12 ambiguous sonnets, perfectly bound together by a unity of tone and inspiration. The collection can be viewed as a collection of Nerval's own experiences and hallucinations. The poems include metaphors of both darkness and light, depicting the poet's hallucinations and wishes respectively. These poems were among the first of their kind in the $19^{\text {th }}$ century. Seemingly classical sonnets by form, they do not fit any categories by content or meter which is proof that Nerval revolutionized the concepts of reality and symbolism. By purifying his soul the poet is inspired by revelations. Accordingly, Nerval's poems are not about this world, but another world of happiness and immortality, for he seems to be looking for a whole other, unknown and mysterious planet where he may find the things he seeks in life. The poet's most important search is for his identity.

The poet's journeys are not only to other countries, but also to madness. Following his first nervous breakdown he lost himself inside hallucinations which he thought were memories. From that time on he obsessively sought his destiny inside his mysterious dreams. News of Jenny Colon's death in 1842 brought on a second breakdown which had him hospitalized in an asylum. From there he wrote his last books - Aurelia: dream and life, and Sylvie - which were published after his death.

Dreams have always carried some notion of divine inspiration. Dreams are a key feature in Nerval's works, specially such works as his autobiographical stories Aurelia and Sylvie: "I can understand everything through these memories and half-dreams" (Nerval, 1965, p. 5 ).

Once hospitalized, Dr. Blanch, his psychiatrist, asked him to bring to paper his recurring dreams. The doctor played an important role in Nerval's interest in dreams. In a letter to his doctor Nerval wrote: "I'll continue writing about my dreams if you want" (Durry, 1956, p. 20). Definitely, writing about his dreams was confusing and the dreams were undoubtedly difficult for Nerval to describe.

For the first time in Les Filles de Feu, particularly in Sylvie, the use of dreams becomes most prevalent. Nerval links his insanity to his dreams and wants their story to be told in silence that "no one dared break the silence" (Nerval, 1965, p. 9). For him, insanity is the waking man's way of dreaming. Nerval had two big sources of inspiration for his descriptions of dreams. Swedenborg's theories and Dante's The Devine Comedy, about which, in the preface to Aurelia, he says: "I tried to copy their work in documenting the effects of this long-lasting malady that presides in the depths of my soul" (Nerval, 1999, p. 3).

These dreams at times appear in the form of points of view. In his own words, Nerval wanted to "document the effects of a long lasting malady," and thus wanted the reader to see through to the depths of his soul. He reveals his thoughts on this experience of sickness in the last pages of Aurelia: "sometimes, I feel blessed for having reached the conclusions that I have and I think of the disasters I have gone through as a sort of descent to hell" (Nerval, 1999, p. 34).

For him, insanity was a revealing source of inspiration, and he looked for ways to transform his views of himself and the world around him. Nerval's views on dreams paved the way for great theorists like Freud and Young to discover the remotest areas of the human subconscious. Nerval found in Swedenborg and Dante "a study of human beings founded on a world of prophesies"(Durry, 1950, p. 32). 
During his stay in the asylum, Nerval used poetry to understand his own dreams and give them meaning and shape. He strove to materialize the swirling haze of his dreams. To make this more clear, Aurelia can be studied form two view-points: first, as a scientific document: Nerval's writing shows subtle hints of psychology and analysis of the disorders of the mind. In Aurelia he tries to give a comprehensive account of the disaster known as insanity. Reading this account helps one understand those inflicted with it. The disaster shows itself once the doctor tries to understand the delicate soul of the inflicted, and recovery is the process accompanied with forgiveness and redemption (Lemaitre, 1956, p. 25) and secondly as a complicated work: an autobiography based on dreams or a story of a lost love, only to be found in another world. Nerval never concernd himself with the poetic form and although the dreams were absurd and indescribable in a sense, Nerval found a way to convey them using the technique of repeating metaphors. At times, his descriptions of dreams sound more real than reality.

Les Filles de Feu is a collection of short stories and the 12 sonnets of Les Chimères published together. Written in the asylum, this book was the outcome of Nerval's attempts to make tangible the fleeting world of dreams. Guided by his memory and with an added element of imagination, he paints a word-picture of his hometown: "my mind sometimes wanders to Valois, and I remember the songs and tales that made up my childhood with much pleasure" (Nerval, 1965, p. 31). In this memoire he writes about the things occupying his mind; his story of life, the countries he grew up in, and his first romantic endeavors and obsession with dreams. Nerval strives to discover an unknown and intangible world in which dreams intermingle with reality. He belongs to a world of symbols and dreams that only exist in his own mind as a strange district. It is safe to say that the poems "Desdichado" and "Artemis" are a sort of alternate autobiography in which the poet relates his memories in the form of myths and legends. As Nerval himself says "I sit daydreaming in a cave filled with floating ferries of Valois" (Nerval, 1965, p. 25) and "I review the details in my head and ask myself, are these real or, better yet, have I dreamt them?" (Nerval, 1965, p. 35). In fact, there is no telling where the memories of the author end and where those of the protagonist begin, again another sign of being inspired by Dante's The Devine Comedy. The author and the protagonist have much in common in Sylvie, where the two live in Paris and have yet to be free of childhood memories. Like the author, the protagonist lives in his own dreams as "a melancholic dreamer; my letters should have convinced you of this by now" (Nerval, 1965, p.16).

The collection of poems is made up of 8 short stories: "Angelique," Sylvie: Souvenirs du Valois (Memories of Valois), "Chansons et Legendes du Valois" (songs and legends from Valois), "Jemmy," "Octavie," "Isis," "Souvenirs de Pompéi" (Memories of Pompeii), "Corilla" and "Emilie." In the collection's second story Sylvie, the role of dreams is most apparent. Also called "Memories of Valois," it is a play on the continuum of time. The story begins in the protagonist's youth and how he falls in love with Aurélie, an actress. "I was leaving the theater in which I gazed upon my love every evening" (Nerval, 1965, p.11) and from there he flashes back to his past where he was enamored by Adrienne as a young adult. "I understand everything through these memories and half-dreams. This intangible, hopeless love for an actress whom I saw every evening at the theater and which wouldn't even leave me alone while asleep had roots in my memories of Adrienne" (Nerval, 1965, p. 32). The protagonist thinks of Aurélie as the embodiment of Adrienne when he says "I told her about the origins of the love I had conceived overnight and had dreamt of afterwards and was now seeing in her" (Nerval, 1965, p. 8).

As the story goes on, he remembers Sylvie and approaches her. This crack in time is observable in two of his other stories, "Les Chimere" and Aurelia. By limiting time, Nerval aims to liberate his subconscious. In Sylvie, time loses its linear meaning and becomes more subjective: "what time is it? That's not my time" (Nerval, 1965, p.29). Nerval believed that the past and the present are inseparable. Accordingly, he presents the imagined past as the present and thus immortalizes the characters. "The three romantic let-downs of the book: leaving Sylvie in part one, losing Aurélie in part 13 and Adrienne's death in part 14, are only let-downs on the surface [...] these surreal heroes will live on for a long time in people's memories" (Richer, 1963, p. 343). In 
"Contre-Sainte Beuve," Proust claims that this story is a "dream within a dream" and Gerard also finds his past in Île-de-France.

"Octavie" is about a man who travels to Italy - As Nerval had done - and begins an affair with an Englishwoman there. Dreams and fantasy take up the majority of this affair, though the actual memories take place in Naples in 1834 and 1843. The story begins with the statement of a doubt: "It might have been the spring of 1835 " and the central theme of the story is suicide followed by bliss and immortality: "in all the hardest moments of his life, suicide seemed to Nerval as the ultimate solution, one that promised an end to this life and an eternity of blissful moments" (Richer, 1963, p. 312). About death, Nerval says "I sometimes fancy that death is floating above a lovely woman, laughing and waiting for me" (Nerval, 1965, p. 3).

Women and the protagonists' love for their lovers make up the subject matter of the other stories in the volume. "Since the age of thirteen, "Angelique" was a melancholy and fanciful sort of person, nothing moved her"(Nerval, 1965, p.18). By and Large, Nerval's obsession with love and death make him comparable with many poets such as John Keats or Charles Baudelaire.

Nerval, like an excavator, digs into the depths of fantasy and dreams and brings them to light. He differentiates between fantasy, point of view and dream a mixture of which can be seen in Aurelia and Sylvie. The realistic view changes in these stories, to the point where even actual dreams within the characters' sleep look like waking reality. Nerval establishes a strange form of continuity between reality and dreams, linking the two worlds. Although best known as a surrealist writer, Nerval makes use of the past rather than the present.

Fantasy has been defined as dreams, view-points and memories in Nerval's writings. The dreams are brief, though the points-of-view are longer and more comprehensible. Aurelia starts with the statement "I was sleeping." Nerval has made appropriate use of the past continuous and past participle tenses which are perfectly proportionate to the storyline. Another aspect of this story is its sense of uncertainty and doubt.

The protagonist seeks an audience with eludes him, because he subconsciously needs to seek the unattainable. And as he goes, he feels so out of place that he actually manages to find himself somewhere unknown, still seeking a moment of rest. "From that point onward a peculiar turmoil comes over me" (Nerval, 1965, p. 5). Reality follows the dream: "I wake with the sweet dream of eventual peace"(Nerval, 1965, p. 82) which implies that only by accepting actions one can understand them.

Freud thought of the dream state as the pathway into he subconscious that helps understand a mental patient. Contrary to Freud's theory that dreams are a reflection of our waking actions, Nerval does not concern himself with the day's events. His dreams are a reflection of his subconscious, a natural extension of reality.

The author views each life as a separate story. Nerval perceives his own life through his dreams, as he believes we all do, and perhaps he wishes to capture that perception. He sees the written language as an unfit instrument in the expression of human emotions which is why dreams and insanity are the two elements that define him and express his emotions. Dreams are the products of each individual's mind and they should be given free rein to express the subconscious. In the $19^{\text {th }}$ century where the hours spent asleep were considered wasted time, these were new ideas brought to the consciousness.

Nerval's ideas are the exact opposite of those of Descartes. For Nerval, dreams are intertwined with insanity, and a dream is a stream of uncertainty and ambiguity. Hegel and Kant are in agreement with this theory, as they too compare the insane to the waking dreamer. Hegel believed that insanity meant dreaming while awake. In his Phenomenology of Spirit, Hegel claims that the difference between sanity and insanity resembles the difference between the states of wakefulness and sleep.

Romantic poets believed that dreams were a sort of divine inspiration or a second life in which there is no running from our fears. Thus romantic poets used this divine inspiration to look into their souls. A dream is a form of communication Nerval uses to create a wondrous reality. In each dream he recreates the one thing the protagonist is lacking: his lost love. This technique 
reveals the actual reality of the story and stretches the limitations of our understanding. The dreams lead the protagonists to their ultimate destination.

Michelle Crozet in his paper "Dream Interpretation" likens the dream-state in Aurelia to what we call the poet's frenzy. In fact the subconscious perfectly comes through in dreams which are a product of the mind and can be a reflection of actions done during the day. In Aurelia and Les Filles de Feu Nerval talk about his purposes in writing the volumes: "Did you say I was crazy? I'm only dreaming" (Nerval, 1965, p. 82).

In Aurelia and Sylvie a balance has been established between the dreams and the dreamer who is a paranoid character, stuck between the real and the surreal, not knowing to which he belongs. "St. Pierre's dome, the Vatican seemed like a dream to me" (Nerval, 1965, p. 82).

A dream is a window into the surreal, and not everyone can understand it. This window opens only when the protagonist has been left alone: "I sometimes feel the need to revisit lonely and fantastic places" (Nerval, 1965, p. 82). Nerval seeks to fill a void within himself with the surreal and the fantastic. The lost love is a subject of these dreams, and thus ever unattainable which is why writing seems to be therapy in Nerval who brought to paper his emotions and experiences as a mental patient in an asylum. As part of his therapy, the doctor had asked him to write about his fantasies and "that's how I managed to rid my head of the ideas long swirling in it. This sick summoning was replaced by scientific ideas" (Nerval, 1965, p. 91). He thought of writing as a form of observation and the remedy to his insanity. Through Aurelia we come to understand a mental patient and eventually find him cured, the point Nerval was trying to prove: "these maladies produce the strangest of ideas [...] my improved state of mind gave me back the love of my family and friends, and I was free to observe and judge the hallucinations I once lived in" (Nerval, 1965, p. 28).

A similar state of dream can be observed in the English romantic poet, John Keats (17951821), who in his poems creates a mysterious world in which dreams and reality are intermingled. When in this world of dreams, he becomes John Keats the poet who creates, and while climbing down the pleasure thermometer and returning to the real world, he changes to John Keats the man who suffers. As, for example, in his "Ode to a Nightingale," (1819) he opens the poem with a poetic description of a dreamy romantic state and contrasts the dreamy world of the nightingale to his own real dark world "where men sit and hear each other groan" ("Ode to a Nightingale," 24: p. 1819). In this ode, reality and dream are interwoven and the boundary between them seems vague as at the end of the poem he asks "Was it a vision, or a waking dream? / Fled is that music:-Do I wake or sleep?" ("Ode to a Nightingale," 79-80: p. 1820). Keats writes about his personal feelings. According to Arjmandi and Lashkarian "there is a difference between the nightingale and the poet. Keats loves the nightingale because it is not aware of the world's agony. It reminds him of his imaginary state in which he was free and cheerful without being conscious of the world" (2014, p. 149).

Similarly, in The Eve of St. Agnes, John Keats who believed that life was a mixture of opposites like death and life; dream and reality; illusion and reality or reality and romance, intermingles the spiritual or dreamy with the physical. In this poem, Keats deals with the love between Porphyro and Madeline, a young maiden who is looking forward to seeing her future husband in a dream on the Eve of St. Agnes. Keats contrasts the spiritual and dreamy world that Madeline experiences in her dream with her physical and luxurious surrounding including Porphyro - Keats also describes the luxuries of the East by referring to the "silken Samarkand" and "ceda'd Lebanon" and creates the East according to his own understanding. In her dream, Madeline experiences a purely divine and spiritual atmosphere as "Her soothed limbs, and soul fatigued away; / Flown, like a thought, until the morrow-day;/ Blissfully haven'd both from joy and pain" (The Eve of St. Agnes, 238-240: p. 1810). In Madeline's dream, Porphyro is an ethereal creature, but when Madeline is awakened by Porphyro's lute playing, her heavenly dreams are spoiled by "a painful change" (Eve, 300: p. 1812) and the spiritual Porphyro she had seen in her dream no longer exists. When Madeline wakes up, like Eve, she is caught between dream and reality, and fears the 
consequence of reality and of losing Porphyro. Madeline draws Porphyro into her vision as he melts into her dream.

Written in the style of a ballad, La Belle Dame Sans Merci that is full of mystery deals with both dreams and a mysterious beautiful lady. The poem tells the story of a "knight-at-arms" who is "alone and palely loitering" (La Belle, 1-2: p. 1814). He meets a beautiful lady who takes him to her cave or "elfin grot" which stands for an underworld where dreams dwell. In this "grot" the knight is lulled to sleep by the lady and dreams "the latest dream I ever dream'd" (La Belle, 35: p. 1815). However, his dream turns to be a nightmare in which he sees "pale kings and princes too" (La Belle, 37: p. 1815) who, like the knight, have been enslaved by the beautiful lady or, as they call her, La Belle Dame Sans Merci who creates the Keatsian negative capability to show the blurred boundary between dream and reality.

Like many other his poems, Keats's Endymion (1818) also involves a state of dream as the opening lines of the poem describe "A bower quiet for us, and a sleep / Full of sweet dreams, and health, and quiet breathing" (Endymion I, 4-5). The poem includes four Books in which Keats deals with both the East and journey into the underworld, since, in quest of his ideal love, Endymion ventures into the underworld and in his journey encounters an Indian maiden. In this poem, as John Kandel notes, Keats "focuses intently upon the poetic intercourse of Endymion and Cynthia" (2001, p. 10). Keats seems to be inspired-at least in Book I where the role of dreams is more apparent-by Dante's The Divine Comedy as both works are presented in the narrative framework of a dream. Endymion opens with a rustic scene of trees, rivers and sheep where shepherds gather while talking together. However, Endymion the "brain-sick shepherd-prince" (Endymion II, 44), who is in a different state, does not participate in their gathering. He sleeps and when awakes, he tells his sister Peona of his encounter with Cynthia and decides to seek his ideal woman, Cynthia, whom he has seen in his dream.

Keats's poem is based upon the Greek myth of Endymion, the shepherd beloved by the moon goddess Selene. However, Keats's eponymous character is not a Greek shepherd loved by a Grecian goddess, but rather, to use John Gibson's words, "merely a young Cockney rhymester, dreaming a phantastic dream at the full of the moon" (qtd. in Gigante, 2001, p. 100). Keats has reversed the situation and talks about the love of Endymion for Cynthia. Moreover, Endymion resembles the protagonist of Percy Bysshe Shelley's Alastor published in 1816. In his preface to Alastor, Shelley praises "the idealist willing to try" while recognizing "the futility of hoping to realize a figment of one's own imagination (Gigante, 2001, p. 72). In fact, both Shelley's and Keats's protagonists quest an ideal love that takes the form of "a female alter ego of the narcissistic poet" (Gigante, 2001, p. 72). Keats's protagonist, however, is more symbolic and allegorical and, thus, can be considered "a double for the modern poet" (Kandel, 2001, p. 10), as line 193 reads that "he was a poet, sure a lover too" (Endymion I). In other words, Endymion and the poet have so much in common; the protagonist in Keats's poem is one and the same as the poet who is searching his identity as a poet in the form of an ideal woman or female alter ego he has seen in his dream. To be more precise, Endymion's quest for his ideal woman resembles Keats the poet's "youthful quest for greatness" (Gigante, 2001, p. 84). In this regard, Kandel points out that "the union of Endymion and Cynthia is poetically engendered, reflecting a poet's romance with the (natural) source of his inspiration" (2001, p. 10).

It is not difficult to understand from Keats's letters that he could tolerate reality, and was not a mere seeker of peace in a dreamy world. According to Levinson, "Keats was afraid of his natural imagination; the enemy in Keats's poetry is inwardness itself (qtd. In Natarajan, 2007, p. 290). In both Nerval and Keats, the significance of dream lies in the fact that it plays the role of a safe haven for the poet who is afraid of the unstable reality and identity. Both seem to seek refuge in dream where a stable identity and a permanent beauty may be found. 


\section{CONCLUSION}

Dreams, as reflections of the subconscious, seem to be an essential ingredient of Nerval's and Keats's poetry. The two poets show that poetry is an apt place to explore the blurred boundary and continuity between dream and reality. This idea seems to be in close relation with both poets' search for identity and inner self. The female figure that, also, appears in many of the two poets' poms is closely related with the poets' obsession with dreams in which they seek to ward off depression and find proof for imagination. Nerval and Keats use poetry to understand their dreams and give them shape and meaning.

\section{References}

[1] Abrams, M. H. et al. (2001). The Norton Anthology of English Literature. New York: Norton.

[2] Arjmandi, N. and Lashkarian, A. (2014). "Two Poets, the Same Desire: A Lacanian Reading of John Keats and Moshiri's Poetry," in Asian Journal of Multidisciplinary Studies. Vol. 2, No. 9, pp. 146-154.

[3] Deote, Georges et al. (1988). Itinéraire littéraire au XIX siècle. Paris: Hatier.

[4] Durry, M. J. (1956). Gérard de Nerval et le mythe. Paris : librairie Générale française.

[5] Gigante, Denise. (2001). The Keats Brothers: The Life of John and George. Massachusetts: The Belknap Press of Harvard University Press.

[6] Kandel, John. (2001). “The Politics of Keats's Early Poetry”. In Susan J. Wolfson (Ed.). The Cambridge Companion to John Keats (pp. 1-19). Cambridge: Cambridge University Press.

[7] Lemaitre, Henri. (1966). Euvre de Nerval. Paris : Garnier.

[8] Natarajan, U. (ed.). (2007). The Romantic Poets. Blackwell Publishing.

[9] Nerval, Gérard de. (1965). Les filles de feu. Paris : Garnier.

[10] Nerval, Gérard de. (1999). Aurélia. Paris: Garnier.

[11] Nodier, Charles. (1957). Contes fantastiques. Paris : Gallimard.

[12] Richer, Jean. (1965). Nerval Expérience Et Création. Paris : Hachette. 